\title{
PELAKSANAAN LELANG EKSEKUSI PANITIA URUSAN PIUTANG NEGARA DITINJAU DARI ASPEK HUKUM ADMINISTRASI NEGARA
}

\author{
Gustina Rahayu Az
}

Universitas Andalas, gustina.rahaynaz@gmail.com

\section{Suharizal}

Universitas Andalas, subarizal_zal@gmail.com

\author{
Diterima: 22 Februari $2019 \quad$ Direvisi: 13 Mei $2019 \quad$ Diterbitkan: 30 Juni 2019
}

\begin{abstract}
The Committee for State Debt Affairs (PUPN), which is in the center of the capital city of the State, is a committee to streamline the implementation of authority and duties. An institution called the State Receivables Affairs Agency was renamed the State Debt and Auction Agency which has now changed the Directorate General State Accounts Receivable and Auction which is then the Directorate General of State Assets, this Agency is directly under and is responsible to the Minister of Finance for operations in the city and regency areas. The Office of State Receivables and Auction Management is formed (hereinafter referred to as KPKNL) the name is the State Wealth and Auction Office (hereinafter referred to as KPKNL). Confiscated Auction of the State Receivables Affairs Committee is an auction carried out on confiscated goods of the State Receivables Affairs Committee which is a debt guarantee at state banks. if given by a government bank to a debtor when faced with a problem the debtor cannot repay his credit payment based on a agreed credit agreement, the bank has taken measures so that the debtor can pay off his credit payments, so in the case of non-performing loans as state accounts uncollectible. This research is a sociological juridical, namely the approach taken to applicable legal norms is related to the facts in the field. That since the issuance of the Decision of the Constitutional Court Number 77 / PUU-IX / 2011 concerning the testing of Law Number 49 Prp Year 1960 concerning the Committee on State Receivables with the State Constitution of the Republic of Indonesia in 1945 resulted in the decision that the Bank's State Owned Enterprise Receivables are not Other State Receivables so that the settlement of Receivables is no longer delegated to the Committee of State Receivables Affairs but the settlement of the Receivables can be settled through the mechanism of each banking company using the principles of a sound banking company. Based on the results of this study, suggestions are suggested. Further study in the State Financial Law relating directly to the State Debt Affairs Committee Execution concerning the delegation of authority previously carried out by the State Debt Affairs Committee under the Minister of Finance was then carried out through the mechanism of each banking company because this is directly related to the accountability of State finances.
\end{abstract}

Keywords: Auction, Committee on State Receivables Affairs, Settlement of Receivables.

\begin{abstract}
Abstrak
Panitia urusan piutang Negara (PUPN) yang berada di pusat ibukota Negara merupakan suatu panitia untuk mengefektifkan pelaksanaan penyelenggaraan wewenang dan tugas, maka dibentuk suatu lembaga yang bernama Badan Urusan Piutang Negara yang berganti nama menjadi Badan Urusan Piutang dan Lelang Negara yang saat ini telah berganti Direktorat Jenderal Piutang dan Lelang Negara yang kemudian Direktorat Jenderal Jenderal Kekayaan Negara, Badan ini berada lansung di bawah dan bertanggung jawab kepada Menteri Keuangan untuk opererasional di daerah-daerah kota dan daerah Kabupaten dibentuk Kantor Pengurusan Piutang dan Lelang Negara (untuk selanjutnya disebut KPKNL yang sekarang berganti nama menjadi Kantor Pelayan Kekayaan Negara dan Lelang (untuk selanjutnya disebut KPKNL). Lelang Sitaan Panitia Urusan Piutang Negara merupakan lelang yang dilaksanakan terhadap barang-barang sitaan Panitia Urusan Piutang Negara yang merupakan jaminan butang di bank-bank pemerintah. Dalam hal pengaturan kredit yang diberikan oleh bank pemerintah kepada Debitur jika dihadapkan pada permasalaban Debitur tidak dapat melunasi pembayaran kreditnya berdasarkan perjanjian keredit yang telah di sepakati, bank telah menempuh upaya-upaya agar Debitur dapat melunasi
\end{abstract}


pembayaran kreditnya, maka dalam hal keredit bermasalah dan macet tersebut sebagai piutang negara yang tidak tertagib. Penelitian ini bersifat yuridis sosiologis yaitu pendekatan yang dilakukan terbadap norma bukum yang berlaku dibubungkan dengan fakta-fakta yang ada dilapangan. Babwa sejak di keluarkannya Putusan Mabkamah Konstitusi Nomor 77/PUU-IX/2011 tentang pengujian Undang-undang Nomor 49 Prp Tabun 1960 tentang Panitia Urusan Piutang Negara dengan Undang-undang Dasar Negara Republik. Indonesia 1945 menghasilkan putusan babwa Piutang Bank. Badan Usaba Milik. Negara bukan merupakan Piutang Negara lagi sehingga penyelesaian Piutang tidak lagi dilimpabkan kepada Panitia Urusan Piutang Negara tetapi penyelesaian Piutangnya dapat diselesaikan melalui mekanisme perusabaan perbankan masing-masing dengan menggunakan prinsip-prinsip perusahaan perbankan yang sehat. Berdasarkan hasil penelitian ini diajukan saran Perlu dilakukan pengkajian lebih lanjut dalam Hukum Keuangan Negara yang berkaitan lansung dengan Lelang Eksekusi Panitia Urusan Piutang Negara mengenai pelimpahan wewenang yang semula di lakukan oleh Panitia Urusan Piutang Negara di bawah Menteri Keuangan kemudian dilakukan melalui mekanisme perusabaan perbankan masing-masing karena hal ini berkaitan lansung dengan pertanggungjawaban keuangan Negara.

Kata Kunci: Lelang, Panitia Urusan Piutang Negara, Penyelesaian Piutang.

\section{PENDAHULUAN}

Pembangunan Nasional bertujuan untuk mewujudkan masyarakat adil dan makmur yang merata baik materil maupun spiritual berdasarkan Pancasila di negara kesatuan Republik Indonesia yang merdeka, berdaulat dan bersatu dalam suasana perikehidupan bangsa yang aman, tentram, tertib dan dinamis. Untuk itu diperlukan pengalokasian yang jelas dalam pengangaran Anggaran Pendapatan Belanja Negara.

Menurut ketentuan Pasal 23 ayat 1 Undang-Undang Dasar 1945, Anggaran Pendapatan dan Belanja Negara sebagai wujud dari pengelolaan keuangan Negara di tetapkan setiap tahun dengan Undang-Undang dan dilaksanakan secara terbuka dan bertanggungjawab untuk sebesar kemakmuran rakyat. Anggaran Negara yang mencakupi semua pengeluaran dan pendapatan yang dirancang secara periodik dengan prosedur tertentu. ${ }^{1}$

Jika ketentuan dalam Pasal 23 UndangUndang Dasar 1945 dikaitkan dengan Keuangan Negara, pada alinea pertama penjelasan Umum Undang-Undang Nomor 17 Tahun 2003 tentang Keuangan Negara menyebutkan:

"Dalam rangka pencapaian tujuan bernegara, sebagaimana tercantum

${ }^{1}$ Muhammmad Djafar, Hukum Kenangan Negara, (Jakarta : Rajawali Pers, 2011), 4 dalam alinea IV Pembukaan UndangUndang Dasar 1945, dibentuk pemerintahan Negara yang menyelenggarakan fungsi pemerintahan dalam berbagai bidang. Pembentukan pemerintahan Negara tersebut menimbulkan hak dan kewajiban negara yang dapat dinilai dengan uang yang perlu dikelola dalam suatu system pengelolaan keuangan Negara”.

Selanjutnya di dalam Ketentuan Pasal 1 angka 1 Undang-Undang Nomor 17 Tahun 2003 tentang Keuangan Negara diatur mengenai pengertian keuangan Negara adalah semua hak dan kewajiban negara yang dapat dinilai dengan uang, serta segala sesuatu baik berupa uang maupun berupa barang yang dapat dijadikan milik Negara berhubung dengan pelaksanaan hak dan kewajiban tersebut. Dalam pengertian ini terdapat kata dijadikan "milik Negara" pada hakikatnya tidak sesuai dengan substansi Pasal 33 ayat (3) Undang-Undang Dasar Tahun 1945. Oleh karena Undang-Undang Dasar Tahun 1945 hanya menempatkan Negara sebagai pihak yang menguasai bukan sebagai pemilik yang dikonkretkan oleh Presiden sebagai Kepala Pemerintah Negara untuk mengelola dan bertanggung jawabkan keuangan Negara. ${ }^{2}$

2 Muhammad Djafar Saidi, Hukum Keunagan Negara Edisi Revisi, (Jakarta: PT. Raja Grafindo Persada, 2011), 11 
Jika ketentuan diatas di kaitkan dengan pengelolaan keuangan negara tersebut harus diselenggarakan secara professional, terbuka dan bertanggungjawab sebagai bagian dari upaya perwujudan tata kelola pemerintahan yang baik (good governance). Selain itu, penyelenggaraan pengelolaan keuangan Negara harus didasarkankan pada penerapan kaidahkaidah yang baik (best practices), seperti akuntabilitas yang berorientasi pada hasil, profesionalisme, proporsionalitas, keterbukaan dan pemeriksaan keuangan oleh Badan pemeriksa yang bebas dan mandiri.

Kemudian dalam hal pengelolaan keuangan negara yang berkaitan dengan penyelesaian piutang Negara berkaitan konsep dasar kebijakan penyelesaian piutang Negara. Dimana penyelesaian piutang Negara yang dimaksud disini adalah penyelesaian utangutang kepada badan-badan, baik yang lansung maupun tidak langsung dikuasai Negara, tidak menggunakan lembaga pengadilan, tetapi melalui Panitia Urusan Piutang Negara sebagai lembaga khusus untuk mengurus piutang Negara, yang diberi kewenangan dan kekuasaan seperti kewenangan dan kekuasaan yang dimiliki pengadilan. ${ }^{3}$

Adapun alasan dibentuknya Lembaga Panitia Urusan Piutang Negara (PUPN) adalah; 1) Sengketa itu menyangkut piutang Negara; 2) Lembaga pengadilan masih belum mampu menyelesaikan sengketa dengan cepat; 3) Untuk mencegah supaya keuangan Negara tidak dirugikan.

Pada dasarnya Panitia urusan piutang Negara (PUPN) yang berada di pusat ibukota Negara merupakan suatu panitia untuk mengefektifkan pelaksanaan penyelenggaraan wewenang dan tugas, maka dibentuk suatu lembaga yang bernama Badan Urusan Piutang Negara yang berganti nama menjadi Badan

\footnotetext{
${ }^{3}$ Soeriaatmaja, AP, Laporan Penelitian AspekAspek Hukum Dalam Penyelesaian Piutang Negara, (Jakarta: Departemen Kehakiman Badan Pembinaan Hukum Nasional, 1993), 87.
}

Urusan Piutang dan Lelang Negara yang saat ini telah berganti Direktorat Jenderal Piutang dan Lelang Negara. Kemudian Direktorat Jenderal Jenderal Kekayaan Negara, Badan ini berada lansung di bawah dan bertanggung jawab kepada Menteri Keuangan untuk opererasional di daerah-daerah kota dan daerah Kabupaten dibentuk Kantor Pengurusan Piutang dan Lelang Negara (untuk selanjutnya disebut KPKNL yang sekarang berganti nama menjadi Kantor Pelayan Kekayaan Negara dan Lelang (untuk selanjutnya disebut KPKNL).

Jika dilihat dari kewenangannya Direktorat Jenderal Kekayaan Negara mempunyai tugas yaitu merumuskan serta melaksanakan kebijakan dan standarisasi teknis di bidang kekayaaan Negara, piutang Negara dan lelang sesuai dengan kebijakan yang ditetapkan oleh Menteri Keuangan dan berdasarkan peraturan perundang-undangan yang berlaku. Dalam melaksanakan tugas tersebut, Direktorat Jenderal Kekayaan Negara menjalankan fungsi: ${ }^{4}$

1. Penyiapan perumusan kebijakan

Departemen Keuangan di bidang kekayaan Negara, piutang Negara dan lelang.

2. Pelaksanaan kebijakan di bidang kekayaan Negara, piutang Negara dan lelang.

3. Penyusunan standarisasi, norma, pedoman, kriteria dan prosedur di bidang kekayaan Negara, piutang Negara dan lelang.

4. Pemberian bimbingan teknis dan evaluasi dibidang kekayaan Negara, piutang Negara dan lelang.

5. Pelaksanaan administrasi Direktoral Jenderal.

Selanjutnya jika dikaitkan dengan fungsi pelaksanaan kebijakan di bidang kekayaan Negara, piutang Negara dan lelang maka untuk kegiatan operasional di daerahdaerah kota dan daerah kabupaten dibentuk

${ }^{4}$ https://www.djkn.kemenkeu.go.id/page/2924/T ugas-dan-Fungsi-DJKN.html diakses pada tanggal 10 Mei 2017, pukul 19.30 WIB 
kantor Pelayanan Kekayaan Negara dan Lelang (KPKNL). Adapun tugas pokok Kantor Pelayanan Kekayaan Negara dan Lelang adalah melaksanakan pelayanan di bidang kekayaan Negara, penilaian, piutang Negara dan lelang. Sementara itu jika dikaitkan dengan tugas Kantor Pelayanan Kekayaan Negara dan Lelang dalam hal pelaksanaan lelang perlu diperhatikan. Keberadaan lelang sebagai fungsi publik maupun privat sangat dibutuhkan. Pelaksanaan lelang sendiri berdasarkan peraturan Menteri Keuangan Nomor 93/PMK.06/2010 sebagaimana telah diubah dengan Peraturan Menteri Keuangan Nomor 106/PMK.06/2013 telah memberi kewenangan Kantor Pelayanan Kekayaan Negara dan Lelang dalam melaksanakan yang sangat luas termasuk diantaranya lelang eksekusi.

Menurut Yahya Harahap yang dimaksud lelang adalah pelelangan dan penjualan barang yang diadakan dimuka umum dengan penawaran harga yang semakin meningkat, dengan persetujuan harga yang makin meningkat, atau dengan pendaftaran harga atau dimana orang-orang yang diundang atau sebelumnya sudah diberitahu tentang pelelangan atau penjualan, atau kesempatan yang diberikan kepada orang-orang yang berlelang atau membeli untuk menawar harga, menyetujui harga atau mendaftarkan.

Jika dilihat dari pelaksanaan lelang itu sendiri dan merujuk pada Pasal 1 ayat 4 Peraturan menteri Keuangan Nomor: 19/PMK.06/2010 tertanggal 23 April 2010, yang dimaksud dengan Lelang Eksekusi adalah:

"lelang untuk melaksanakan putusan dan atau penetapan pengadilan, dokumendokumen lain yang dipersamakan dengan itu, dan/atau melaksanakan

${ }^{5}$ M. Yahya Harahap, Ruang Lingkup Permasalaban Eksekusi Bidang Perdata, (Jakarta: PT.Gramedia, 1989), 115 ketentuan dalam peraturan perundangundangan".

Bertitik tolak pada ketentuan Pasal 1 ayat 4 Peraturan menteri Keuangan Nomor : 19/PMK.06/2010 tertanggal 23 April 2010, maka lelang eksekusi terdiri dari beberapa hal yaitu:

1. Lelang Eksekusi Panitia Urusan Piutang Negara.

2. Lelang Eksekusi Pengadilan.

3. Lelang Eksekusi Pajak.

4. Lelang Eksekusi Harta Pailit.

5. Lelang Eksekusi pasal 6 Undang-Undang Hak Tanggungan.

6. Lelang Eksekusi dikuasai/tidak dikuasai Bea Cukai.

7. Lelang Eksekusi Barang Sitaan Pasal 45 Kitab Undang-Unadang Hukum Acara Pidana (KUHAP).

8. Lelang Eksekusi Barang Rampasan.

9. Lelang Eksekusi Barang Temuan.

10.Lelang Eksekusi Fidusia.

11.Lelang Eksekusi Gadai.

Pelaksanaan Lelang sudah diatur di dalam Peraturan Menteri Keuangan Nomor 27/PMK.06/2016, tanggal 22 Februari 2016, berkaitan dengan Peraturan Menteri Keuangan Nomor 106/PMK.06/2013 tentang Perubahan Atas Peraturan Menteri Keuangan Nomor 93/PMK.06/2010 tentang Petunjuk Pelaksanaan Lelang. Didalam Pasal 1 angka PMK Nomor 27/PMK.06/2016 menyatakan bahwa, Lelang adalah Penjualan barang yang terbuka untuk umum dengan penawaran harga secara tertulis dan/atau lisan yang semakin meningkat atau menurun untuk mencapai harga tertinggi yang didahului dengan pengumuman lelang.

Pasal 1 angka 4,5,6 Peraturan Menteri Keuangan Nomor 27/PMK.06/2016 mengklasifikasikan lelang menjadi:

1. Lelang Eksekusi yaitu lelang untuk melaksanakan Putusan atau penetapan pengadilan, dokumen-dokumen lain yang di 
persamakan dengan itu, dan/atau melaksanakan ketentuan dalam peraturan perundang-undangan.

2. Lelang Non Eksekusi Wajib yaitu lelang untuk melaksanakan penjualan barang yang oleh peraturan perundang-undangan di haruskan di jual secara lelang.

3. Lelang Non Eksekusi Sukarela yaitu Lealang atas barang milik swasta, perorangan atau badan hukum/badan usaha yang di lelang secara sukarela.

Secara Hukum Administrasi Negara Piutang Negara merupakan bagian dari kekayaan negara yang oleh undang-undang diserahkan pengelolaannya kepada Menteri Keuangan. Oleh karena itu piutang negara harus dikelola secara tertib, efektif, efisien, transparan, bertanggungjawab, taat pada peraturan perundang-undangan yang berlaku serta dengan memperhatikan rasa keadilan dan kepatutan. Dalam rangka pengelolaan piutang negara tersebut terdapat 2 (dua) unit organisasi di lingkungan Departemen Keuangan, yaitu Panitia Urusan Piutang Negara (PUPN) dan Direktorat Jenderal Piutang dan Lelang Negara (DJPLN). Kedua unit organisasi tersebut berada di bawah dan bertanggungjawab langsung kepada Menteri Keuangan.

Tujuan dibentuknya Panitia Urusan Piutang Negara dan Direktorat Jenderal Pelayanan Lelang Negara tidak terlepas dari tujuan pemerintah untuk mengamankan kekayaan negara yang berupa piutang. Piutang negara tersebut berasal dari instansi pemerintah dan badan-badan yang modalnya sebagian atau seluruhnya dikuasai oleh negara. Pengamanan/pengembalian piutang negara tersebut tidak akan tercapai dengan segera bila dilakukan menurut prosedur biasa, yaitu melalui badan peradilan berdasarkan hukum acara perdata (HIR: Herizene Indonesisch Reglement, Staatsblad 1941 No.44).

Dalam menyelesaikan piutang negara, Panitia Urusan Piutang Negara dan/atau Direktorat Jenderal Piutang dan Lelang Negara menempuh prosedur khusus (Lex Specialis) yaitu prosedur pengurusan piutang sebagaimana diatur dalam Undang-undang Nomor 49 Prp. Tahun 1960 beserta segenap peraturan pelaksanaannya yang tertuang dalam berbagai Peraturan Pemerintah, Keputusan Presiden, Keputusan Menteri Keuangan. Selain itu, dalam melaksanakan tugasnya Panitia Urusan Piutang Negara dan/atau Direktorat Jenderal Piutang dan Lelang Negara juga memperhatikan ketentuan peraturan perundang-undangan lain yang terkait, seperti Undang-undang Keuangan Negara, Undangundang Perbendaharaan Negara dan undangundang lainnya.

Di samping itu Lelang Sitaan Panitia Urusan Piutang Negara merupakan lelang yang dilaksanakan terhadap barang-barang sitaan Panitia Urusan Piutang Negara yang merupakan jaminan hutang di bank-bank pemerintah. Dalam hal pengaturan kredit yang diberikan oleh bank pemerintah kepada Debitur jika dihadapkan pada permasalahan Debitur tidak dapat melunasi pembayaran kreditnya berdasarkan perjanjian kredit yang telah di sepakati, bank telah menempuh upayaupaya agar Debitur dapat melunasi pembayaran kreditnya, maka dalam hal kredit bermasalah dan macet tersebut sebagai piutang negara yang tidak tertagih. Untuk pengurusan piutang negara karena kredit macet yang berasal dari bank pemerintah sebelum berlakunya Peraturan Pemerintah Nomor 33 Tahun 2006 tentang perubahan atas Peraturan Pemerintah Nomor 14 Tahun 2005 tentang Tata cara penghapusan Piutang Negara/Daerah, diserahkan Pihak Bank pada Panitia Urusan Piutang Negara. Panitia Urusan Piutang Negara khusus diadakan untuk mengurus kepentingan keuangan negara, hutang kepada negara atau badan-badan baik yang secara lansung ataupun tidak langsung 
dikuasai oleh negara. ${ }^{6}$ Dengan kata lain dalam hal ini mengenai barang yang dikuasai oleh pemerintah secara tidak lansung berada di sektor perbankan khususnya barang jaminan dari bank pemerintah yang ketika terjadi kredit macet di serahkan ke Panitia Urusan Piutang Negara karena secara tidak lansung hal ini berkaitan erat dengan keuangan negara.

Dalam ketentuan Pasal 2 huruf g Undang-Undang Nomor 17 Tahun 2003 tentang keuangan negara, dikatakan bahwa:

"kekayaan negara/kekayaan daerah yang dikelola sendiri atau oleh pihak lain berupa uang, surat berharga, piutang, barang, serta hak-hak lain yang dapat dinilai dengan uang, termasuk kekayaan yang dipisahkan pada perusahaan negara/perusahaan daerah".

Dari ketentuan Pasal 2 huruf g maka dapat dikatakan bahwa keuangan negara juga meliputi kekayaan negara yang dipisahkan. Kemudian dalam penjelasan undang-undang Keuangan Negara diperjelas mengenai ruang lingkup dan pengertian keuangan negara. Objek dari keuangan negara salah satunya berasal dari kekayaan negara yang dipisahkan. Kekayaan Negara yang dipisahkan merupakan kekayaan negara yang berasal dari Anggaran Pendapatan dan Belanja Negara untuk dijadikan penyertaan modal negara pada Persero dan/atau Perum serta perseroan terbatas lainnya sebagaimana diatur dalam Undang-undang Nomor 19 tahun 2003 tentang Badan Usaha Milik Negara.

Definisi kekayaan negara yang dipisahkan menurut pasal 1 angka 10 UndangUndang Badan Usaha Milik Negara adalah yang pada intinya penyertaan modal negara yang dalam Persero dan/atau perum maupun Perseroan Terbatas lainnya berasal dari Anggaran Pendapatan Belanja Neagara yang merupakan bagian dari kekayaan negara.

${ }^{6}$ Mariam Darus Badrulzaman, Perjanjian Kredit Bank, (Bandung: Alumni, 1980), 151

${ }^{7}$ Pasal 1 Angka 10 Undang-undang Nomor 19 Tahun 2003 Tentang Badan Usaha Milik Negara.
Kedua penjelasan pasal di atas memberi arti bahwa Badan Usaha Milik Negara sebagai suatu badan usaha yang modalnya berasal dari APBN (keuangan negara) yang dipisahkan serta berlaku prinsip-prinsip perusahaan yang sehat bukan lagi pengelolaannya mengikuti sistem keuangan negara. Apabila segala aset maupun kekayaan yang dimiliki Badan Usaha Milik Negara disamakan dengan keuangan negara maka akibatnya hukumnya, segala kekayaan Badan Usaha Milik Negara baik berupa uang, surat berharga, piutang, barang, serta hak-hak lain yang dapat dinilai dengan uang, apabila terjadi kerugian maka itu termasuk kerugian negara, maka negaralah yang menanggungnya.

Penyelesaian piutang negara yang semula dilaksanakan melalui lembaga khusus seperti Panitia Urusan Piutang Negara dan Badan Penyelesaian Piutang Negara, pada saat ini dapat ditempuh melalui beberapa jalur hukum antara lain melalui Panitia Urusan Piutang Negara atau Badan Penyelesaian Utang dan Lelang Negara (PUPN/BPULN), melalui Peradilan Umum, Peradilan Niaga, dan melalui Arbitrase atau Alternatif Penyelesaian Sengketa (mediasi \& negosiasi). Jalur-jalur penyelesaian yang dipilih tersebut menjadi tidak efektif karena kemungkinan putusannya sulit dieksekusi, serta tidak efisien karena proses litigasinya berjalan lamban, lama, mahal dan berbelit-belit. ${ }^{8}$

Namun sejak di keluarkannya Putusan Mahkamah Konstitusi Nomor 77/PUUIX/2011 tentang pengujian Undang-undang Nomor 49 Prp Tahun 1960 tentang Panitia Urusan Piutang Negara dengan Undangundang Dasar Negara Republik Indonesia 1945 menghasilkan putusan bahwa Piutang Bank Badan Usaha Milik Negara bukan merupakan Piutang Negara lagi sehingga penyelesaian Piutang tidak lagi dilimpahkan kepada Panitia Urusan Piutang Negara tetapi

8 Muhammad Djumhana, Hukum Perbankan di Indonesia, (Bandung : PT Citra Aditya Bakti, 2000), 430 
penyelesaian Piutangnya dapat diselesaikan melalui mekanisme perusahaan perbankan masing-masing dengan menggunakan prinsipprinsip perusahaan perbankan yang sehat.

Jika dilihat dari segi pelaksanaannya dalam hal kredit macet yang terdapat pada bank-bank pemerintah kebanyakan dilakukan melalui peradilan umum dan melalui Arbitrase atau Alternatif Penyelesaian Sengketa (mediasi \& negosiasi) pada dasarnya yang semula dilakukan oleh Panitia Urusan Piutang Negara tidak terlihat lagi Fungsi Panitia Urusan Piutang Negara dalam melakukan Penyelesaian Piutang Negara yang terdapat pada bank-bank pemerintah. Terkait dengan hal diatas, Kantor Pelayanan Kekayaan Negara dan Lelang (KPKNL) Padang juga melaksanakan Lelang Eksekusi yaitu dalam hal Lelang Eksekusi Panitia Urusan Piutang Negara.

Semenjak diberlakukannya Putusan Mahkamah Konstitusi Nomor 77/PUUIX/2011 tentang pengujian Undang-undang Nomor 49 Prp Tahun 1960 tentang Panitia Urusan Piutang Negara dengan Undangundang Dasar Negara Republik Indonesia 1945, Kantor Pelayanan Kekayaan Negara dan Lelang Padang melaksanakan lelang eksekusi Panitia Urusan Piutang Negara terkait kredit macet yang dilakukan oleh bank-bank pemerintah dilakukan secara lelang eksekusi Hak Tanggungan. Namun dalam pengamatan Penulis terkait penyelesaian kredit macet pada bank-bank pemerintah pada Kantor Pelayanan Kekayaan Negara Kota Padang tidak efektif disebabkan oleh lamanya waktu yang dibutuhkan oleh pihak-pihak yang terkait dalam proses penyelesaian lelang.

Dengan menggunakan metode Yuridis Empiris, artikel ini memfokuskan pembahasan tentang bagaimanakah pelaksanaan Lelang Eksekusi Panitia Urusan Piutang Negara ditinjau dari Aspek Hukum Administrasi Negara. Selain itu fokus pembahasan ini juga mengkaji tentang bagaimana akibat hukum pelaksanaan Lelang Eksekusi Panitia Urusan
Piutang Negara semenjak di berlakukannya Putusan Mahkamah Konstitusi Nomor 77/PUU-IX/2011 dan pertanggungjawaban secara Hukum Administrasi Negara.

\section{LELANG DALAM HUKUM ISLAM}

Kajian Lelang adalah bagian dari pembahasan Fiqib Muamalah. Aktivitas Lelang sudah eksis dari zaman Rasulullah yang biasa disebut dengan dengan muzayadah atau saling menambahkan). Ulama berbeda persepsi terkait hukum-nya, apakah dibolehkan atau justru dilarang dengan status hukum makruh.

Kalangan yang mengatakan bolehnya Lelang berdalil bahwa Nabi SAW pernah melakukan aktivitas Jual-Beli Lelang. Seperti sebuah Hadis yang diriwayatkan dari Anas bahwa Rasulullah SAW pernah menjual sebuah pelana unta dan sebuah mangkuk. Ketika Beliau menawarkan barang dagangannya tersebut, seseorang menyahut dan bersedia membelinya seharga satu dirham. Lalu Nabi menawarkan kepada siapa saja yang berani menambahi. Maka diberi dua dirham oleh seorang laki-laki kepada beliau, lalu terjual kedua benda itu. (HR Tirmidzi).

Sebagian lagi menilainya sebagai aktivitas terlarang dengan kadar hokum Makruh. Dengan dalil bahwa Rasulullah pernah melarang seseorang membeli barang yang sudah ditawar oleh saudaranya/orang lain (sama halnya ketika Rasulullah melarang meng-khitbah wanita yang sedang di khitbah oleh orang lain/saudaranya). Hadis dari Ibnu Umar bahwa Rasulullah SAW melarang seseorang membeli sesuatu yang sedang dibeli oleh saudaranya hingga dia meninggalkannya, kecuali rampasan perang dan waris (HR. Bukhari Muslim).

Proses jual-beli secara lelang adalah ketika terjadi jual-beli dengan menyertakan uang tanda-jadi/DP, maka tidak diperkenankan barang yang hendak di lelang tersebut di tawarkan ke orang lain untuk dijual. Oleh karena itu jika terdapat uang tanda-jadi 
perlu diberikan batas waktu sampai kapan tanda-jadi tersebut berlaku. Jika sampai bataswaktu ternyata belum dilakukan pelunasan jual-beli, maka penjual diperkenankan untuk menjual barang tersebut ke orang lain. Lelang tidak diperbolehkan jika terdapat unsur kecurangan dalam bentuk apapun seperti pemalsuan dokumen atau persekongkolan.

\section{PELAKSANAAN LELANG EKSEKUSI PANITIA URUSAN PIUTANG NEGARA DITINJAU DARI ASPEK HUKUM ADMINISTRASI NEGARA}

Pada Kantor Pelayanan Kekayaan Negara dan Lelang (KPKNL) Padang untuk Pelaksanaan Lelang Eksekusi Panitia Urusan Piutang Negara terkait penyelesaian Piutang Negara pada bank-bank pemerintah seperti bank-bank Badan Usaha Milik Negara sejak tahun 2015 sudah tidak pernah dilaksanakan Lelang. ${ }^{9}$ Di mana semenjak dikeluarkannya Putusan Mahkamah Konstitusi Nomor 77/PUU-IX/2011 tentang pengujian Undangundang Nomor 49 Prp Tahun 1960 tentang Panitia Urusan Piutang Negara dengan Undang-undang Dasar Negara Republik Indonesia 1945 yang menghasilkan putusan bahwa Piutang Bank Badan Usaha Milik Negara bukan merupakan Piutang Negara lagi sehingga penyelesaian Piutang tidak lagi dilimpahkan kepada Panitia Urusan Piutang Negara tetapi penyelesaian Piutangnya dapat diselesaikan melalui mekanisme perusahaan perbankan masing-masing dengan menggunakan prinsip-prinsip perusahaan perbankan yang sehat. Pelaksanaan yang dilakukan oleh Bank-Bank Pemerintah seperti Bank-Bank Badan Usaha Milik Negara dalam hal kredit macet atau bermasalah dilakukan Lelang secara Eksekusi Hak Tanggungan.

Semenjak dikeluarkannya Putusan Mahkamah Konstitusi Nomor 77/PUU-

${ }^{9}$ Rizki Suhendra, Kepala Seksi Verifikasi Panitia Urusan Piutang Negara KPKNL Padang, Wawancara, tanggal 05 Maret 2018.
IX/2011 mengenai Pelaksanaan Lelang Eksekusi Panitia Urusan Piutang Negara yang berhubungan dengan Bank-bank pemerintah tidak menjadi kewenangan Panitia Urusan Piutang Negara lagi. Hal ini tentunya berdampak terhadap resiko pengendalian atas pengelolaan piutang menjadi lebih besar. Resiko pengendalian yang dimaksud adalah makin terbuka peluang penyalahgunaan hak pengurusan' piutang. Mengingat pemerintah tidak lagi terlibat secara langsung dalam penyelesaian piutang-piutang bermasalah. Berdasarkan Putusan Mahkamah Konstitusi Nomor 77/PUU-IX/2011 tanggal 25 September 2012, diantaranya Panitia Urusan Piutang Negara tidak dapat lagi melakukan pengurusan piutang Badan Usaha Milik Negara/Badan Usaha Milik Daerah terkait kredit macet, yang mengakibatkan bidang pengurusan Piutang Negara yang dilakukan oleh Panitia Urusan Piutang Negara sejak pasca keputusan bergeser yang awalnya adalah pengurusan dilakukan melalui Panitia Urusan Piutang Negara menjadi pembinaan dalam pengelolaan Piutang Negara/daerah. Atas hal tersebut Direktorat Jenderal Kekayaan Negara harus melaksanakan pengelolaan piutang Negara/daerah yang memiliki tujuan yaitu:

1. Piutang Negara/Daerah dapat tertagih secara tepat berdasar koridor hukumnya.

2. Akuntabilitas penyelenggaraan tugas pemerintah.

3. Dapat menyajikan Laporan Keuangan Pemerintah Pusat/Daerah dengan akuntabel.

Di samping itu terdapat juga pergeseran kewenangan yang semula secara Hukum Administrasi Negara Piutang Negara merupakan bagian dari kekayaan negara yang oleh undang-undang diserahkan pengelolaannya kepada Menteri Keuangan diambil alih oleh Badan Usaha Milik Negara melalui mekanisme perusahaan perbankan masing-masing dengan menggunakan prinsipprinsip perusahaan perbankan yang sehat. 


$\begin{array}{lcr}\text { AKIBAT } & \text { HUKUM } & \text { PELAKSANAAN } \\ \text { LELANG } & \text { EKSEKUSI } & \text { PANITIA } \\ \text { URUSAN } & \text { PIUTANG } & \text { NEGARA } \\ \text { SEMENJAK } & \text { DI } & \text { BERLAKUKANNYA } \\ \text { PUTUSAN } & \text { MAHKAMAH KONSTITUSI } \\ \text { NOMOR } & \text { 77/PUU-IX/2011 } & \text { DAN } \\ \text { PERTANGGUNGJAWABAN } & \text { SECARA } \\ \text { HUKUM ADMINISTRASI NEGARA }\end{array}$

Sejak dikeluarkannya Putusan

Mahkamah Konstitusi Nomor 77/PUU IX/2011, dimana Mahkamah Konstitusi memutus uji materi beberapa pasal dalam Undang-Undang Nomor 49/Prp/1960 tentang Panitia Urusan Piutang Negara. Pasalpasal yang diuji dalam uji materi tersebut antara lain pasal 4, pasal 8, pasal 10, dan pasal 12 ayat (1). Adapun yang menjadi subtansi dari putusan ini yaitu mengenai tidak berwenangnya lagi Panitia Urusan Piutang Negara untuk melaksanakan Lelang Eksekusi Panitia Urusan Piutang Negara terhadap penanganan kredit macet pada bank-bank pemerintah.

Bank Badan Usaha Milik Negara merupakan bank yang sebagian atau keseluruhan modalnya dimiliki oleh negara melalui penyertaan secara langsung yang berasal dari kekayaan negara yang dipisahkan. Hal tersebut tertuang dalam Undang-Undang Nomor 19 tahun 2003 tentang Badan Usaha Milik Negara.

Ada beberapa hal yang menjadi prinsip pokok dalam pengurusan Piutang Negara yaitu. ${ }^{10}$

\section{Pengertian Piutang Negara}

Menurut Pasal 8 Undang-Undang Nomor 49 Prp. Tahun 1960, yang dimaksud dengan Piutang Negara adalah jumlah uang yang wajib di bayar kepada negara atau badanbadan yang baik secara lansung maupun tidak lansung dikuasai oleh negara berdasarkan suatu

10 S. Mantayborbir, S.H,M.H, dkk, Pengurusan Piutang Negara Macet pada PUPN/BUBPLN: Suatu Kajian Teori dan Praktik, (Medan: 2011), 62-66 peraturan, perjanjian atau sebab apapun. Dalam Penjelasan pasal 8 ditegaskan bahwa yang dimaksud dengan piutang negara adalah hutang yang:

1. Lansung terhutang kepada Negara dan Oleh Karena itu harus di bayar kepada Pemerintah Pusat atau Pemerintah Daerah.

2. Terhutang terhadap badan-badan yang umumnya kekayaan dan modalnya sebagian atau seluruhnya milik negara.

3. Adanya dan besarnya telah pasti menurut hukum.

Berdasarkan pasal 12 Undang-Undang Nomor 49 Prp. Tahun 1960 instansi-instansi pemerintah dan badan-badan negara wajib menyerahkan pengurusan Piutang Negara kepada Panitia Urusan Piutang Negara (PUPN) yang adanya dan besarnya teah pasti menurut hukum, akan tetapi penanggung hutang tidak melunasi hutangnya sebagaimana mestinya.

Adapun proses yang ditempuh untuk menentukan piutang yang adanya dan besarnya teah pasti menurut hukum dengan melakukan penelitian atas piutang yang akan diserahkan dengan terlebih dahulu diakukan oleh penyerah piutang.

Selain itu Panitia Urusan Piutang Negara (PUPN) sendiri dalam menerima penyerahan Piutang Negara mewajibkan kepada penyerah piutang untuk menyerahkan dokumen-dokumen yang berkaitan dengan penyerahan piutang macet tersebut guna dapat membuktikan secara hukum kepastian tentang adanya dan besarnya piutang negara yang macet tersebut.

\section{$\underline{\text { Piutang Macet }}$}

Di dalam Undang-Undang Nomor 49 Prp Tahun 1960 tidak dijumpai istilah piutang macet atau kredit macet. Pengertian Piutang Macet dapat dipedomani dari penjelasan pasal 4 Undang-Undang Nomor 49 Prp. Thaun 1960 yaitu "Piutang Negara pada tingkat pertama pada prinsipnya di selesaikan oleh instansi-instansi 
dan badan-badan yang bersangkutan". Dari penjelasan pasal 4 Undang-Undang Nomor 49 Prp. Tahun 1960 dapat diartikan bahwa Piutang Negara baru dikategorikan macet setelah instansi atau negara yang bersangkutan mengupayakan penyelesaian sesuai dengan ketentuan intern instansi dan badan yang bersangkutan.

Pengurusan Piutang Negara khusus (Parate Executie)

Pengurusan piutang negara sebagaimana diatur dalam pasal 11 UdangUndang Nomor 49 Prp. Tahun 1960 dilakukan secara khusus, tidak menggunakan prosedur HIR (Saatblad 1941 Nomor 44). Panitia Urusan Piutang Negara (PUPN) berwenang mengambil langkah hukum untuk menyelesaikan Piutang.

Semenjak dikeluarkannya Putusan Mahkamah Konstitusi Nomor 77/PUU IX/2011, pelaksanaan eksekusi dalam hal kerdit macet pada bank-bank pemerintah penyelesaian Piutangnya dapat diselesaikan melalui mekanisme perusahaan perbankan masing-masing dengan menggunakan prinsipprinsip perusahaan perbankan yang sehat. Eksekusi dilakukan berdasarkan eksekusi Hak Tanggungan untuk benda tetap dan eksekusi Fidusia untuk benda bergerak.

Secara Hukum Administrasi Negara Piutang Negara merupakan bagian dari kekayaan negara yang oleh undang-undang diserahkan pengelolaannya kepada Menteri Keuangan dan semenjak dikeluarkannya Putusan Mahkamah Konstitusi Nomor 77/PUU-IX/2011 tentang pengujian Undangundang Nomor 49 Prp Tahun 1960 tentang Panitia Urusan Piutang Negara dengan Undang-undang Dasar Negara Republik Indonesia 1945 yang menghasilkan putusan bahwa Piutang Bank Badan Usaha Milik Negara bukan merupakan Piutang Negara lagi sehingga penyelesaian Piutang tidak lagi dilimpahkan kepada Panitia Urusan Piutang
Negara tetapi penyelesaian Piutangnya dapat diselesaikan melalui mekanisme perusahaan perbankan masing-masing dengan menggunakan prinsip-prinsip perusahaan perbankan yang sehat. Pelaksanaan yang dilakukan oleh Bank-Bank Pemerintah seperti Bank-Bank Badan Usaha Milik Negara dalam hal kredit macet atau bermasalah dilakukan Lelang secara Eksekusi Hak Tanggungan.

Dalam pertimbangannya Mahkamah Konstitusi menerangkan bahwa tugas Panitia Urusan Piutang Negara dalam UndangUndang Nomor 49 Prp tahun 1960 tentang Panitia Urusan Piutang Negara mengenai pengawasan terhadap piutang-piutang yang telah dikeluarkan oleh badan-badan negara. Untuk itu terhadap ketentuan tersebut, telah mengalami tumpang tindih dengan UndangUndang Nomor 10 Tahun 1998 tentang Perbankan. Termasuk juga tumpang tindih terhadap Undang-undang Nomor 19 Tahun 2003 tentang Badan Usaha Milik Negara dan Undang-Undang Nomor 40 tahun 2007 tentang Perseroan Terbatas.

Berdasarkan hal-hal tersebut, Mahkamah Konstitusi memutuskan bahwa: ${ }^{11}$

1. Frasa "atau badan-badan yang dimaksudkan dalam Pasal 8 Peraturan ini”, dalam Pasal 4 ayat (1) Undang-Undang Nomor 49 Tahun 1960 adalah bertentangan dengan Undang-Undang Dasar 1945 dan tidak mempunyai kekuatan hukum mengikat.

2. Frasa "badan-badan negara" dalam Pasal 4 ayat (4) Undang-undang Nomor 49 Tahun 1960 adalah bertentangan dengan Undang-Undang Dasar 1945 dan tidak mempunyai kekuatan hukum mengikat.

3. Frasa "atau badan-badan yang baik secara langsung atau tidak langsung dikuasai negara" dalam Pasal 8 Undang-Undang Nomor 49 Tahun 1960 adalah bertentangan dengan Undang-Undang Dasar 1945 dan

${ }^{11}$ Dijelaskan dalam Amar Putusan Mahkamah Konstitusi Nomor 77/PUU-IX/2011 
tidak mempunyai kekuatan hukum mengikat.4.Frasa "atau badan-badan negara” dalam Pasal 12 ayat (1) UndangUndang Nomor 49 Tahun 1960 adalah bertentangan dengan Undang-Undang Dasar 1945 dan tidak mempunyai kekuatan hukum mengikat.

Berdasarkan hal diatas akibat hukumnya adalah bahwa frasa "badan-badan" yang terdapat pada Undang-Undang Nomor 49 Prp Tahun 1960 tentang Panitia Urusan Piutang Negara bertentangan dengan Undang-Undang Dasar 1945 dan tidak mempunyai kekuatan hukum mengikat dan seluruh piutang negara yang telah diserahkan oleh "badan-badan" kepada Panitia Urusan Piutang Negara tidak dapat lagi penyelesainnya dilakukan oleh Panitia Urusan Piutang Negara. Dengan demikian berarti seluruh piutang negara yang sudah diserahkan ke Panitia Urusan Piutang Negara harus dikembalikan kepada pihak internal bank Badan Usaha Milik Negara yang telah menyerahkannya.

Kedudukan Badan Usaha Milik Negara sebagai kreditur dalam bidang perbankan yaitu sebagai pemberi kredit kepada nasabahnya (debitur). Kredit merupakan transaksi utang-piutang antara bank dengan nasabahnya dengan jangka waktu tertentu. Kadang kala tidak semua debitur melaksanakan pembayaran kredit secara tepat waktu bahkan hingga menunggak cukup lama, sehingga tagihan-tagihan kredit kepada nasabah menjadi piutang milik bank tersebut.

Oleh karena bank yang melakukan transaksi kredit bentuknya Badan Usaha Milik Negara, maka piutang bank yang dimaksudkan adalah berstatus milik Badan Usaha Milik Negara yang bersangkutan, sehingga penyelesaian piutang bank yang berstatus milik Badan Usaha Milik Negara dilaksanakan oleh pihak bank itu sendiri sesuai dengan ketentuan Undang-Undang
Badan Usaha Milik Negara mengenai pembinaan dan pengelolaan Badan Usaha Milik Negara tidak didasarkan pada mekanisme Anggaran Pendapatan dan Belanja Negara, melainkan didasarkan pada prinsipprinsip perusahaan yang sehat. Oleh karena itu, dapat ditafsirkan bahwa piutang Badan Usaha Milik Negara tidak lagi dikatakan sebagai piutang negara, sehingga tidak berlaku ketentuan Undang-Undang Panitia Urusan Piutang Negara. ${ }^{12}$

Pada Kantor Pelayanan Kekayaan Negara Padang (KPKNL) Padang setelah adanya Putusan Mahkamah Konstitusi Nomor 77/PUU-IX/2011 tentang pengujian Undangundang Nomor 49 Prp Tahun 1960 tentang Panitia Urusan Piutang Negara dengan Undang-undang Dasar Negara Republik Indonesia 1945, terakhir kali dilakukan lelang terhadap lelang eksekusi Panitia Urusan Piutang Negara pada tahun 2015, dimana terdapat 3 Objek yang dijadikan barang bangunan yaitu:

1. Sebidang Tanah Sertipikat Hak Milik Nomor: 140, tercatat atas nama Haji Anwar Syukur, terletak di Sungai Bangek, Kecamatan Koto Tangah seluas $14.050 \mathrm{M}^{2}$.

2. Sebidang Tanah Sertipikat Hak Milik Nomor: 1480, tercatat atas nama Anwar Syukur, terletak di Jalan Khatib Sulaiman dan Belanti Raya, Kecamatan Padang Utara seluas $1.235 \mathrm{M}^{2}$.

3. Sebidang Tanah Sertipikat Hak Milik Nomor: 202, tercatat atas nama Marjalis, terletak di Nagari Koto Tangah Kecamatan Koto Tangah seluas $65.265 \mathrm{M}^{2}$.

Terhadap Objek sertipikat tersebut diatas sampai pada saat ini masih belum laku terjual. untuk pelaksanaan lelang setelah berlakunya Putusan Mahkamah Konstitusi Nomor 77/PUU-IX/2011, diserahkan kepada

12 Wiwin Sri Rahyani, "Problematika Penyelesaian Piutang BUMN Dalam Peraturan Perundang-Undangan”, Jurnal Rechtsvinding Media Pembinaan Hukum Nasional, (Jakarta), 2 
Bank dengan menunggu keputusan pusat karena hal ini secara tidak lansung berkaitan dengan penyelesaian piutang negara di bawah kementerian keuangan.

Hal ini seharusnya tidak menjadi tanggung jawab Panitia Urusan Piutang Negara lagi dalam upaya penyelesaian kredit bermasalah pada bank-bank pemerintah mengingat sejak dikeluarkannya putusan Mahkamah Konstitusi Nomor 77/PUUIX/2011 yang menjelaskan bahwa Badan Usaha Milik Negara tidak lagi dikatakan sebagai piutang negara, sehingga tidak berlaku ketentuan Undang-Undang Panitia Urusan Piutang Negara. Sehingga secara tidak lansung tanggung jawab penuh telah diserahkan kepada Badan Usaha Milik Negara sebagai penerima kewenangan dalam menyelesaikan permasalahan kredit macet tersebut. Tetapi bukan berarti menunggu kembali keputusan dari pusat sehingga dapat menimbulkan kepastian hukum dan efektivitas hukum dalam penyelesaian kredit bermasalah pada perusahaan perbankan yang berhubungan lansung dengan Badan Usaha Milik Negara.

\section{KESIMPULAN}

Berdasarkan hasil penelitian yang penulis lakukan pada Kantor Pelayanan Kekayaan Negara dan Lelang Kota Padang tentang Pelaksanaan Lelang Eksekusi Panitia Urusan Piutang Negara Ditinjau Dari Aspek Hukum Administrasi Negara didapatkan beberapa hal.

Setelah di keluarkannya Putusan Mahkamah Konstitusi Nomor 77/PUUIX/2011 terdapat pergeseran kewenangan yang semula secara Hukum Administrasi Negara Piutang Negara merupakan bagian dari kekayaan negara yang oleh undang-undang diserahkan pengelolaannya kepada Menteri Keuangan melalui Panitia Urusan Piutang Negara diambil alih oleh Badan Usaha Milik Negara melalui mekanisme perusahaan perbankan masing-masing dengan menggunakan prinsip-prinsip perusahaan perbankan yang sehat.

Putusan Mahkamah Konstitusi Nomor 77/PUU-IX/2011 telah mengalami tumpang tindih dengan Undang-Undang Nomor 10 Tahun 1998 tentang Perbankan. Termasuk juga tumpang tindih terhadap Undang-undang Nomor 19 Tahun 2003 tentang Badan Usaha Milik Negara dan Undang-Undang Nomor 4 tahun 2007 tentang Perseroan Terbatas terkait kekayaan negara yang dipisahkan. Hal ini dapat menimbulkan ketidakpastian hukum dan efektifitas dari pelaksanaan lelang Eksekusi Panitia Urusan Piutang Negara disebabkan oleh lamanya waktu yang dibutuhkan oleh pihak-pihak yang terkait dalam proses penyelesaian lelang yang terkait dengan penyelesaian kredit macet pada Perusahaan Perbankan yang termasuk dalam Badan Usaha Milik Negara.

Sebagai saran, perlu dilakukan pengkajian lebih lanjut dalam Hukum Keuangan Negara yang berkaiatan lansung dengan Lelang Eksekusi Panitia Urusan Piutang Negara mengenai pelimpahan wewenang yang semula di lakukan oleh Panitia Urusan Piutang Negara di bawah Menteri Keuangan kemudian dilakukan melalui mekanisme perusahaan perbankan masingmasing karena hal ini berkaitan lansung dengan pertanggungjawaban keuangan Negara.

Selain itu, perlu dilakukan pengkajian ulang mengenai sejauh mana lingkup objek untuk penyelesaian Lelang eksekusi Panitia Urusan Piutang Negara dimana Objek terhadap benda yang sudah masuk dalam pengurusan penyelesaian di KPKNL setelah dikeluarkannya Putusan Mahkamah Konstitusi Nomor 77/PUU-IX/2011 sehingga menciptakan kepastian hukum terhadap objek yang belum selesai penyelesaiannya di KPKNL yang penyelesaiannya dilimpahkan ke Pusat. 


\section{DAFTAR KEPUSTAKAAN}

Amar Putusan Mahkamah Konstitusi Nomor 77/PUU-IX/2011

AP, Soeriaatmaja, Laporan Penelitian Aspek-Aspek Hukum Dalam Penyelesaian Piutang Negara, Jakarta: Departemen Kehakiman Badan Pembinaan Hukum Nasional, 1993.

Badrulzaman, Mariam Darus, Perjanjian Kredit Bank, Bandung :Alumni, 1980.

Djafar, Muhammmad, Hukum Keuangan Negara, Jakarta : Rajawali Pers, 2011.

Djumhana, Muhammad, Hukum Perbankan di Indonesia Cetakan 3, Bandung : PT Citra Aditya Bakti, 2000.

Harahap, M. Yahya, Ruang Lingkup Permasalahan Eksekusi Bidang Perdata, Jakarta : PT.Gramedia, 1989.

Mantayborbir, S., S.H,M.H, dkk, Pengurusan Piutang Negara Macet pada PUPN/BUBPLN : Suatu Kajian Teori dan Praktik, Medan: 2011.

https://www.djkn.kemenkeu.go.id/page/2924/Tugas-dan-Fungsi-DJKN.html (diakses pada tanggal 10 Mei 2017, pukul 19.30 WIB )

Pasal 1 Angka 10 Undang-undang Nomor 19 Tahun 2003 Tentang Badan Usaha Milik Negara.

Rahyani, Wiwin Sri, "Problematika Penyelesaian Piutang BUMN Dalam Peraturan Perundang-Undangan”, Jurnal Rechtsvinding Media Pembinaan Hukum Sasional, Jakarta.

Saidi, Muhammad Djafar, Hukum Keunagan Negara Edisi Revisi, Jakarta : PT. Raja Grafindo Persada, 2011. 